\title{
Biblica
}

et

\section{Shawn Colberg}

Saint John's University

Patristica

Thoruniensia

e-mail: scolberg@csbsju.edu

ORCID: 0000-0003-0438-784X

12 (2019) 3: 271-287

DOI: http://dx.doi.org/10.12775/BPTh.2019.015

ISSN (print) 1689-5150

ISSN (online) 2450-7059

\section{Development in Aquinas's Theology of Grace and the Role of Saint Augustine}

\section{Rozwój teologii łaski Akwinaty i rola św. Augustyna}

\begin{abstract}
This study explores the place of Saint Augustine's mature theology of grace in the thought and development of Saint Thomas Aquinas on the same subjects. It begins with a review of Thomas's Scriptum super sententiis, highlighting its stress on the formal effects of grace and wide appreciation for human merit. It then surveys three significant developments in the Summa theologiae, noting the introduction of divine auxilium as a category for grace, a pronounced stress on fallen human nature, and a reframed account of merit focused on divine ordinatio. The study notes the Summa's citation of Augustine's anti-Massilian works. It concludes that while Thomas's mature theology is indebted to Augustine and Saint Paul, it also offers a reconceived framework for grace which makes Augustine's positions on predestination, perseverance, and merit more viable for $13^{\text {th }}$ century theology
\end{abstract}

Streszczenie. Studium analizuje miejsce dojrzałej teologii łaski świętego Augustyna w myśli i rozwoju świętego Tomasza z Akwinu w odniesieniu do tych samych tematów. $\mathrm{Na}$ początku autor dokonuje przeglądu Scriptum super sententiis Tomasza z Akwinu, podkreślając jego nacisk na formalne skutki łaski i szerokie uznanie dla ludzkiej zasługi. Następnie bada trzy znaczące kierunki rozwoju w Sumie teologicznej, zwracając uwage na wprowadzenie boskiego auxilium jako kategorii łaski, wyraźnego nacisku na upadłą ludzką naturę i przeformułowanego opisu zasługi skoncentrowanego na boskim ordinatio. Artykuł zwraca uwagę na cytowane w Sumie teologicznej dzieła antymasylijskie Augustyna. Konkluzją studium jest stwierdzenie, że chociaż dojrzała teologia Tomasza pozostaje dłużna Augustynowi i św. Pawłowi, jednak oferuje ona również przemyślane na nowo ramy łaski, dzięki czemu stanowisko Augustyna dotyczące przeznaczenia, wytrwania i zasługi jest bardziej realne dla trzynastowiecznej teologii.

Keywords: Aquinas; Augustine; nature; grace; justification; merit; perseverance; predestination and $\sin$.

Słowa kluczowe: Akwinata; Augustyn; natura; łaska; usprawiedliwienie; zasługa; wytrwanie; przeznaczenie i grzech. 
Se aint Thomas Aquinas's mature theology in the Summa theologiae deploys an enriched and refined understanding of grace. ${ }^{1}$ It demonstrates theological development over his early work in the Scriptum super sententiis, particularly regarding the nature of grace and the roles of divine and human action. The Summa theologiae's treatise on grace (I-II:109-114) makes explicit use of Augustine's On the Predestination of the Saints and On the Gift of Perseverance, and its positions on conversion, perseverance, and eternal life resonate with those of the late Augustine. ${ }^{2}$ This study argues that Thomas's mature theology of grace insists on the absolute primacy of sanctifying grace including an emphasis on divine motion that circumscribes and directs human cooperation toward the goal of eternal life; moreover, this development reflects an appreciation of Augustine's anti-Massilian theology. To that end, it first exposits Thomas's early understanding of grace and human action in the Scriptum; it then elucidates key advances found in the Summa theologiae, noting the way in which these features acknowledge Augustine and other sources; and finally, it concludes that Thomas's mature theology of grace offers an original framework for renewed engagement with the Doctor of Grace. What emerges is a recognition that Thomas's early theology of grace gives way to more nuanced understand-

1 Foundational studies on this topic include H. Bouillard's Conversion et grace chez S. Thomas d'Aquin. Etude historique (Paris 1944), B. Lonergan's Grace and Freedom: Operative Grace in the Thought of St. Thomas Aquinas, (London 1971), and J. Wawrykow's God's Grace and Human Action: 'Merit' in the Theology of Thomas Aquinas (South Bend 1995). Wawrykow also offers a useful introduction to Aquinas's mature teaching on grace in "Grace," in The Theology of Thomas Aquinas, Rik Van Nieuwenhove and Joseph P. Wawrykow (eds.), (South Bend 2005), 192-221. See further S. Colberg "Aquinas and the Grace of Auxilium," Modern Theology 32 (2016) 207-09 and The Wayfarer's End: Bonaventure and Aquinas on Divine Rewards in Scripture and Sacred Doctrine, (Washington, D.C. forthcoming). J. Wawrykow also treats of the Augustinian influence on Thomas in "Perseverance in $13^{\text {th }}$-Century Theology: the Augustinian Contribution," Augustinian Studies 22 (1991) 125-40.

2 Late in his career (c. 427), Augustine receives inquiries from Prosper of Aquitaine and a bishop named Hilary concerning the initium of conversion, with the suggestion that human beings can initiate their faith and God then supplements this initial movement. In response, Augustine composes a work that has come to modern readers as two treatises: On the Predestination of the Saints and On the Gift of Perseverance (c. 428). Translations of On the Predestination of the Saints and On the Gift of Perseverance are taken from Four AntiPelagian Writings, J. Mourant and J. Collinge (trans.), (Washington, D.C. 1992), 218-337. Critical studies of Augustine's mature theology of grace include J.P. Burns's The Development of Augustine's Doctrine of Operative Grace, (Paris 1980), G. Bonner's Freedom and Necessity: Saint Augustine's Teaching on Divine Power and Human Freedom, (Washington, D.C. 2007), and Lenka Karfikova's Grace and the Will according to Augustine, (Leiden: Brill, 2014). 
ing of divine action that better illumines the varied experiences of the graced believer's movement toward union with God.

\section{Grace and Merit in the Scriptum}

Thomas's magisterial commentary on Peter Lombard's Sentences illumines his early thinking on grace, justification, and merit. Largely faithful to the Lombard's organization and procedure in the Sentences, the Scriptum (1252-56) follows Peter's treatment of grace and merit in Book II, distinctions 26 to 29. ${ }^{3}$ It also shows continuity with Thomas's $13^{\text {th }}$ century contemporaries who collectively emphasize the formal effects of sanctifying grace. ${ }^{4}$ Thomas the baccalarius similarly stresses that the effects of gratia gratum faciens primarily bridge the ontological division between God and human beings; it makes recipients pleasing to God by making them deiform and capacitating them for corresponding action. He writes: "Therefore it holds that the first gift [of grace], which is infused into the person freely, has the effect of elevating the essence of the soul to be divine, and so [the person] is made suitable for divine works." 5 Human beings are made in the image of God and stand capax Dei; sanctifying grace capacitates, perfects, and extends the formal nature of humankind to participate in divine action. ${ }^{6}$ Human nature itself is limited to natural or finite ends so that sanctifying grace necessarily elevates the form to participate in the supernatural life of God and perform works commensurate with that status: "Grace confers on the soul a perfection of a certain divine nature, and not only as it pertains to works; to a certain extent, it constitutes having dei-formity, just as children [of God], and for that reason they are called the graced ones by God."' Sanctifying grace is necessary and gratuitous; the soul cannot progress unless God infuses the habitual gift of grace which in its finitude humanity cannot naturally deserve.

As a corollary to stressing the formal effects of grace, the Scriptum foregrounds the role of human agency for meritorious works. The graced recipient must make good use of grace and advance toward union with God. The discus-

3 Thomas offers a treatment of justification in Scriptum, 4 Sent, d. 17.

4 Cf. J. Wawrykow's “Perseverance," pp. 127-29.

5 Scriptum super libros sententiarum (hereafter Scriptum,) 2 Sent d. 26 q. 1 a. 3 co. Translations of the Scriptum are mine and taken from Thomas Aquinas, Scriptum super libros sententiarum, 4 vols., P. Mandonnet and M. F. Moos, eds., (Paris 1933-47).

6 Cf., Scriptum, 3 Sent d. 27. a. 2 ad. 3 or 3 Sent d. 27 a. 4 sol.

7 Scriptum, 2 Sent d. 26 q. 1 a. 4 ad. 3. 
sion of operative versus cooperative grace at the end of Distinction 26 makes this explicit. Taking up a distinction used by Augustine in De Gratia et Libero Arbitrio 17, Thomas outlines an order for the effects of grace; he writes:

It should be said that grace has diverse and ordered effects in us. For the first effect which it accomplishes is that this [grace] gives a certain divine being. The second effect is the works of merit which cannot be done apart from grace. The third effect is the reward of merit, namely, the life of the blessed which is prevened by grace. ${ }^{8}$

Operative divine agency gives way to cooperative human agency following the provision of sanctifying grace, leaving the recipient disposed for good works. Thomas further stratifies the effects of grace according to a twofold movement of the human will. Grace is operative when it heals and elevates the will internally - disposing it to act. Grace is cooperative when the will executes its choices in exterior action. ${ }^{9}$ Thomas further aligns operative grace with prevenient grace and cooperative grace with subsequent grace so that grace is operative when it prevenes the interior will's movement or good wish, and it is cooperative when it follows - as a meritorious act - from the will's consequent movement to execute its choice. ${ }^{10}$ Ultimately, the onus falls on the human actor to actualize these gifts of grace through good works which deserve the reward of eternal life.

The Scriptum establishes ample ground for human merit in three crucial moments of human life: gaining eternal life, progressing in grace, and effecting

8 Scriptum, 2 Sent 26 q. 1 a. 5 co. Thomas follows the Lombard's treatment "De gratia operante et cooperante" at 2 Sent., d. 26, chapter 161 where Peter draws on Augustine's De Gratia et Libero Arbitrio for the working distinction between operation and cooperation; this connection links Augustine to later scholastic discussions of operative and cooperative grace. Augustine also references human cooperation with divine grace in De correptione et gratia, 8.17, De natura et gratia, 33, and Ep. 194. Cf. B. Lonergan, Grace and Freedom, pp. 2-11 for a discussion of Augustine's insights on operating grace and its integration into the Lombard's Sentences.

9 Cf. Scriptum, 2 Sent d. 26 q. 1 a. 5 co.

10 Cf. especially Scriptum, 2 Sent d. 26 q. 1 a. 5 ad. 2, where Thomas speaks of operative grace as having habitual and efficient effects; he writes: "To the second it should be said that operating grace is called operative, in one sense, in the soul not efficiently (non effective) but formally, according to which any form is made to be in a subject, just as whiteness is made to be white; whence through this mode grace is called operating, because grace formally makes persons pleasing to God. But in another way, grace is called operating in an efficient way, according to which the habit (habitus) efficiently causes works..." In this early account of operating and cooperating graces, efficient outcomes of operative grace still flow from the infused habit in the recipient which prompts, by its capacity, the recipient to good works. 
the grace of conversion. To the first, Thomas reasons that human beings may merit eternal life as a condign reward, that is, as a reward where there is equality between the meritorious work and the reward itself. To maintain the condignity of eternal life, Thomas argues that it is not the "quantity" of a person's works which has condignity; it is their "proportion." While human beings cannot aggregate a total number of good works deserving of eternal life, they can do work which, in its quality, has condignity with the reward of eternal life. ${ }^{11}$ The infusion of sanctifying grace establishes supernatural habits which make possible good works which are supernatural in their quality, for example, works of surpassing faith, hope or love. A deiform person may do deiform acts, and when done under the right conditions, they are equal to and worthy (dignus) of the reward of eternal life.

Thomas explores meriting the first grace of conversion. He denies the plain sense of this position, writing that "the gift of grace never can fall under merit for those who are in a state of pure nature and much less for those who have been brought low through sin." 12 Even those in a state of natura pura cannot make a just claim by which they deserve sanctifying grace; they lack the ontological standing to do so. This is even less conceivable for sinners who deserve punishment rather than reward. Nevertheless, interpreters of Thomas dispute

11 Cf. Scriptum, 2 Sent d. 27 q. 1 a. 3 co. Wawrykow writes "If we think of the equality of proportion, says Aquinas, it is possible to affirm condign merit before God. God grants the same reward to those who have done the same virtuous action and who therefore have merited in the same way. God's observation of the same measure insures the equality of proportion" (God's Grace, p. 73).

12 Scriptum, 2 Sent d. 27 q. 1 a. 4 co. It is important to distinguish between sanctifying grace (gratia gratum faciens) and gratia gratis data (sometimes called gratuitous grace) which, in the Scriptum, is characterized as a divine movement in the economy that prompts the recipient to action; like many contemporaries including Saint Bonaventure, Thomas understands gratia gratis data to arouse sinners to conversion; cf. Scriptum, 2 Sent d. 28 q. 1 a. 4 co where Thomas writes: "And so without gratia gratis data a person may not prepare himself for grace, even though gratia gratis data is called an act of the free will, which God works in us, and by which we prepare ourselves for sanctifying grace (gratiam gratum facientem)." In the present question, Thomas explores whether a person may merit sanctifying grace, presumably, after being prompted by gratia gratis data but before receiving gratia gratum faciens making justification possible. Importantly, Thomas refines the meaning of gratia gratis data in Summa Theologiae (hereafter ST) I-II: 111, $1 \mathrm{c}$ as a gift of the Holy Spirit which helps to lead others - not oneself - to conversion; he writes: "And according to this, grace is twofold: one through which a person is united to God, which is called gratia gratum faciens, and another through which one person cooperates for leading one to God, and this gift is called gratia gratis data, because it is added beyond the capability of nature and beyond the merit of the person." Translations of the Summa theologiae are mine and drawn from Summa theologiae, 5 vols., (Ottawa 1941-1945). 
the question of congruent or proportional merit of the first grace. Some see the Scriptum's not infrequent affirmation of the maxim "facienti quod in se est" as evidence of a kind of inchoate congruent merit of the first grace. ${ }^{13}$ For example, when discussing whether one is able to fulfill the divine precepts apart from grace, Thomas writes: "For if one prepares by doing what is in oneself, grace undoubtedly follows through which one is able to merit eternal life." ${ }^{14}$ While Thomas does not describe this as a condign reward, he sees human preparation for justification in causal terms. A congruency exists between the limited through genuine effort of the sinner and God's response such that Thomas identifies justifying grace as a response to the authentic action of the sinner. The position leaves open the possibility of human merit for the first grace of conversion.

Lastly, human beings possess capacious powers to advance meritoriously in sanctification by their efforts. Thomas affirms that persons may "dispose themselves for the increase of grace through acts which issue from the infused habits of grace and charity." ${ }^{15}$ Free cooperation with sanctifying grace leads to increases in that same grace. He adds: "a person having grace is not said to be able to progress in the good as if he could grow in grace by himself, since growth in grace is from God, but because a person is able to merit growth in grace through the reception of grace, by disposing himself, he is capacitated for a greater grace." 16 While grace is needed in order to merit further perfection in grace, human beings can and must cooperate by right actions. Because Thomas largely conceives of grace according to its formal effects, further perfection of those forms is possible as part of the life of grace. Notably, Thomas forgoes any discussion of the role or need for perseverance in the articles on grace and merit. Continuance in a state of grace is largely assumed unless it is

13 Cf. J. Wawrykow, God's Grace, pp. 84-85, n. 47-49.

14 Scriptum, 2 Sent d. 28 q. 1 a. 3 ad 5. Cf. Scriptum, 2 Sent d. 28 q. 1 a. 4 co. Twelfth century theologians developed an explanation around this saw that sought to elucidate the respective roles of God and human beings in the moment of conversion. The argument often asserts that, in light of Christ's saving action, God makes grace generally available to human beings - perhaps in something like a concursus generalis or a particular instance of gratia gratis data. Individuals may follow its prompting toward the process of conversion by exercising their free will. When the sinner demonstrates a committed desire for repentance and conversion - facienti quod in se est - God responds with justifying grace to facilitate the conversion.

15 Scriptum, 2 Sent d. 27 q. 1 a. 5 ad 4.

16 Scriptum, 2 Sent d. 27 q. 1 a. 5 ad 4. Cf. Scriptum, 2 Sent d. 27 q. 1 a. 5 ad. 3. 
broken by a mortal sin. ${ }^{17}$ Absent is any reference to subsequent falls from grace or what might be needed to remain in the state of grace, for example, in moments of temptation. Thomas does not deal with the lingering effects of concupiscence such that concupiscence might inhibit merit or require further provisions of grace. The formal and habitual effects of sanctifying grace suffice to equip the recipient for progress so that merit frames much of the conversation around discipleship, virtue, and growth in holiness.

\section{Grace and Merit in the Summa theologiae}

Thomas culminates the prima-secundae of the Summa theologiae with the treatise on grace. His mature theology of sanctifying grace features three developments subsequent to the Scriptum. They significantly illumine his mature exposition of human salvation. First, in the initial articles of prima-secundae 109, Thomas distinguishes sanctifying grace as habitual and as auxilium. Showing continuity with parts of the Scriptum, habitual grace (gratiae habitualis donum) pertains to the human form; it heals and elevates that form, capacitating its habits or virtues as steady dispositions to action. It accomplishes the sanans et elevans effects of grace. Thomas pairs the formal effects of grace with the motive effects of auxilium divinum, sometimes referred to as helping or actual grace. Auxilium connotes God's application of motion to the human form. ${ }^{18}$ Thomas summarizes: "For it was said above that a person is helped by the gratuitous will of God in two ways. One way [is] insofar as the person's soul is moved by God to know or will or do something. And in this mode the gratuitous effect in the person is not a quality but some movement of the soul; for 'motion is the act of the mover in the moved (moventis in moto est motus)."'19 The stress on the soul's internal movement reflects the idea that something must actualize a person's potential acts or habits. God's motion, working through human nature, does so in order that a person may participate in the movement toward eternal

17 Cf. J. Wawrykow, "Perseverance," pp. 126-27 for its treatment of continuance in grace.

18 Thomas sometimes elides the term auxilium with habitual grace, but he consistently retains a narrow meaning for the term that connotes God's application of persons to their acts. Wawrykow writes: "For auxilium in this [narrow] sense, see such texts as I-11 109, 1c, where he calls it divinum auxilium, I-II 109, 2c (divinum auxilium), I-II 109, 3c (auxilium Dei moventis, auxilium Dei), I-II 109, 4c (auxilium Dei moventis), I-II 109, 5 ad 3 (auxilium gratiae), and 109, 6c (auxilium gratuitum Dei interius animam moventis)" (God's Grace, p. 171, note 52).

19 ST I-II: 109, $1 \mathrm{c}$. 
life. ${ }^{20}$ Using the habitual versus auxilium distinction, Thomas parses the effects of God's grace with greater precision and, in turn, identifies instances of prevenient divine action in justification and sanctification; such instances are less perceptible with the lens of habitual grace alone. Aquinas's development of auxilium as motion has no direct connection to Augustine though it coincides with his encounters of Augustine's anti-Massilian texts and increasing appreciation of divine providence and predestination. ${ }^{21}$ The conceptual framework for auxilium rests on Thomas's greater use of the Aristotelian notion of premotion and its integration with the idea of "application" so that God - as outside of the created order - applies motion to created things in order to effect the divine will in the economy. This increasing awareness of God as mover and efficient cause of discrete movements across the cosmos informs Thomas's sense of sanctifying grace as both formal and efficient. ${ }^{22}$ Augustine's category of operating grace provides a conceptual home for these insights.

The Summa's position shows significant development from Scriptum's treatment of operative and cooperative graces. As in the Scriptum, Thomas quotes Augustine to frame his position: "But on the contrary Augustine says in the De Gratia et Libero Arbitrio 'By cooperating in us God perfects that which God began by operating in us, because the one who begins by operating so that we might will [is] the one who perfects by cooperating with those who are willing." 23 Thomas distinguishes the effects of grace where God is the sole agent and the recipient is simply disposed or moved by the grace; he describes them as operative. God alone receives credit for the term of the action (or the effect) because God is the sole actor. The human recipient could describe such

20 Thomas likens a person lacking divine auxilium to a soldier who is formally or naturally capable of seeking victory but remains motionless apart from the command of the leader of the army who reduces the solider to action (ST I-II: 109, $6 \mathrm{c}$ ).

21 Cf. H. Bouillard, Conversion et grace, pp. 113-14 for the original argument that, prior to writing the Summa contra Gentiles, Thomas encountered Augustine's De praedestinatione sanctorum and De dono perseverantiae. Thomas references On the Predestination of the Saints at 2 Sent. d. 27 q. 1 a. 6 s.c. 1, but the citation is likely drawn from a compendium of sayings.

22 Thomas conceives of divine power outside the temporal order; Lonergan writes: "The Thomist higher synthesis was to place God above and beyond the created orders of necessity and contingence: because God is universal cause, His providence must be certain; but because $\mathrm{He}$ is transcendent cause, there can be no incompatibility between terrestrial contingence and the cause of certitude of providence" (Grace and Freedom, p. 79).

23 ST I-II: 111, 2 sc. 
graces as gift. ${ }^{24}$ Thomas also recognizes effects of grace where God initiates the movement or infuses the gift in such a way that the recipient responds freely to God and thus co-operates with God's action; Thomas describes them as cooperative. ${ }^{25}$ In such instances, both God and the human person receive credit for the effect because both were agents in bringing about its term. The human actor might describe such an outcome as, in part, a reward for his cooperation. Gone is the association of operative grace with prevenient grace and cooperative grace with subsequent grace. In its stead is a twofold structure of habitual and actual graces that can have either operative or cooperative effects depending on the status and needs of the recipient. ${ }^{26}$

A second critical distinction in the Summa's treatise on grace is its consistent distinction between intact and fallen human nature. ${ }^{27}$ Human beings always stand in need of habitual grace and auxilium in order to reach the supernatural end of union with God, yet sin and its consequences complexify the ways in which grace is needed. Prior to the fall, intact human nature had natural capacities proportionate to its nature though it still required surpassing gifts of faith and love, for example, to accomplish goods proportionate with supernatural rewards. Fallen nature, however, stands in significantly more need of grace. Sin not only incurs punishment according to justice; it corrupts the natural good of human nature so that the wayfarer cannot do all of the good all of the time that is required for progress. ${ }^{28}$ Thomas regularly invokes the effects

24 Thomas writes: "Therefore in those effects in which our mind is moved and does not move, but in which God alone is moving, the operation is attributed to God, and accordingly this is called 'operating grace."' (ST I-II: 111, 2 c).

25 Thomas writes: "But in those effects in which our mind both moves and is moved, the operation is not attributed alone to God but also to the soul, and accordingly this is called 'cooperating grace."' (ST I-II: 111,2 c).

26 ST I-II: 111, 2 observes two vital moments of operative auxilium: (1) the moment when the sinful will begins to will good and (2) the continuance of the wayfarer in a state of grace which includes progress to the end of eternal beatitude. Both instances mark important development from the Scriptum; cf. J. Wawrykow, "Perseverance," p. 131 and S. Colberg "Auxilium," pp. 197-98.

27 Thomas writes: "I answer that the nature of a person may be considered in two ways, in one way as in its integrity, just as it was in our first parents prior to sin, and in another according to the way in which it was corrupted in us after the sin of our first parents" (ST I-II: 109, 2 c). Thomas argues in ST I-II: 85, 3 that sin "wounds" human nature by disordering the natural order of intellect, will, and lower appetites. He carries a sense of this disorder over to the justified wayfarer whose irascible will and concupiscence remain unconformed to the movement of the restored intellect and will.

28 Thomas writes: "And therefore in a state of natural integrity a person needs a gratuitous strength superadded to the strength of nature for one reason, namely, in order 
of sin as reason for ongoing provisions of sanctifying grace in the remaining questions and articles of the treatise on grace. For example, in the final articles of Question 109, Thomas asks whether a person, once possessed of grace, can maintain himself in that state of grace. Following the general thrust of the Scriptum, one might expect affirmations of habitual grace and God's initial inspiration of the wayfarer to be adequate for maintaining life in a state of grace. In the Summa, however, Thomas notes that habitual grace heals the soul but does not reorder it to a prelapsed state, particularly in the flesh; it does not capacitate a person to avoid all venial sin or to withstand the effects of concupiscence. Rather, gifts of auxilium - as discrete applications of motion which reduce corresponding potencies to actions - cause the perseverance of the recipient in grace. Thomas writes:

Therefore regarding the first mode of help, a person in a state of grace does not need another help of grace, such as another infused habit. ...For although healed through grace as to the mind, it nevertheless remains corrupted and infected in the flesh, through which it serves "the law of sin" as is said in Romans 7:25. A certain obscurity [darkness] of ignorance also remains in the intellect according to which it is written in Romans 8:26: "We do not know not what we ought to pray for...." And for that reason we need to be protected and guided by God, who knows everything and is able [to do] everything. And for that reason also, for those born again as children of God in grace, it is fitting to say: "Lead us not into temptation," and "Thy will be done on earth as it is in heaven," and whatever else is contained in the Lord's Prayer pertaining to this. ${ }^{29}$

Temptation remains an on-going threat for persons in a state of grace because concupiscence lingers even after the reception of habitual grace. ${ }^{30}$ Thomas draws on Paul's conclusion in Rom. 7:25 that, even for the justified, the mind

to do and wish supernatural good. But in the state of corrupt nature two reasons, namely, in order to be healed, and ultimately in order to do works of supernatural virtue, which are meritorious. Yet beyond this, in both states, man needs the divine auxilium so that he may be moved to act well" (ST I-II: 109, 2 c).

29 ST I-II: 109,9 c.

30 Importantly, Thomas argues that auxilium effecting perseverance differs from habitual grace or other auxilia such as the preparation for grace. He goes so far as to say that "To many grace is given to whom perseverance in grace is not given" (ST I-II: 109, $10 \mathrm{c}$ ). In ST I-II.109, 10 ad. 3, drawing on Augustine (On Nature and Grace, 43), Thomas stresses the necessity of perseverance by suggesting that prelapsed Adam had the capacity or habit to persevere while he lacked the gift of perseverance. The former refers to habitual grace which remains in potency without the latter gift of auxilium to actualize it. 
serves the "law of God" while the flesh serves the "law of sin." ${ }^{11}$ Augustine cites this same passage in On the Predestination of the Saints to affirm the priority of divine grace for any salutary human action. In the Summa's treatise on grace, Thomas appeals to passages from the Lord's Prayer that petition God to "lead" and "deliver" persons away from temptation and evil. Similar references are made by Augustine in his late anti-Massilian works. ${ }^{32}$ In On the Gift of Perseverance, for example, Augustine writes: "For this indeed the saints, who do the will of God, also pray, saying the Prayer, 'Thy will be done.' Since it has already been accomplished in them, why do they still ask that it be done, unless that they may persevere in that which they have begun to be?"33 Thomas's mature insistence on auxilium thus illustrates both critical anthropological insights about fallen human nature as well as greater familiarity with the late Augustine and on-going exposition of the Pauline corpus. ${ }^{34}$ These theological insights insist that habitual grace, by itself, is an inadequate theological category for understanding the on-going agency of God in the conversion, continuance in a state of grace, and merit.

Thomas's greater emphases on operative and cooperative auxilium as well as the fallen state of human nature narrow the scope of human merit originally affirmed in the Scriptum, and it marks a third critical development in the Summa theologiae's treatise on grace. In the proemium to the discussions on justification and merit, for example, Thomas writes: "We have now to consider the effect of grace; first the justification of the ungodly, which is the effect of op-

31 For insight into the way that Thomas cites scripture in his systematic works, see P. Roszak's “The Place and Function of Biblical Citations in Thomas's Aquinas's Exegesis," in Reading Sacred Scripture with Thomas Aquinas: Hermeneutical Tools, Theological Questions, and New Perspectives, P. Roszak and J. Vijgen, (eds.), (Turnhout), 115-140.

32 In On the Gift of Perseverance, Augustine appeals to the Lord's Prayer to demonstrate that persons naturally implore God to complete, through grace, what they cannot do solely through human efforts. He cites Cyprian's De dominica oratione and offers an extended discussion of the ways in which the Lord's Prayer connotes the need for divine perseverance in sections 2.2-13.33. Augustine makes similar though less detailed references in On the Predestination of the Saints (8.15).

33 Augustine, On the Gift of Perseverance 3.6. For more on Augustine and perseverance cf. J.P. Burns, The Development, pp. 168-74.

34 Torrell dates Thomas's completion of the Prima Secundae to 1271 at the end of the second Parisian regency, while Thomas's final lectures on Romans 1-8 were likely given in 1272-73; cf. J.P. Torrell's Saint Thomas Aquinas, v. 1, Robert Royal (trans.), (Washington, D.C. 1996), p. 340. Bouillard notes with some effect the increasing appreciation of Paul in Thomas's late works in Conversion et grace, pp. 135-150. 
erating grace; and second, merit, which is the effect of cooperating grace." ${ }^{35}$ This taxonomy is telling. Thomas reckons that justification is an effect of operative grace so that the human actor cannot be credited with its outcome; the language of merit is excluded. Indeed, the Summa concludes that the classic use of the facienti quod in se est cannot be licit. Rather, any salutary action for justification is actualized by divine auxilium; "doing what is in oneself" cannot earn the grace of conversion, though it can mark the operative preparation of the sinner for justification. When treating the facienti, Thomas explicitly cites $O n$ the Gift of Perseverance; he writes: "But [conversion] may be considered, secondly, as it is from God the Mover, and thus it has a necessity - not indeed of coercion, but of infallibility - as it regards what is ordained by God, since God's intentions cannot fail, according to the saying of Augustine in his book on the Predestination of the Saints (De Dono Persev xiv) that by God's good gifts whoever is liberated, is most certainly liberated." 36 Thomas thus departs from much of the high scholastic tradition on human preparation for justification, deploying the late Augustine for authority.

The Summa retains meaningful conceptual space for merit in prima-secundae 114, but Thomas shifts from the rationales from those offered in the Scriptum. Gone is the discussion of proportionally condign merit. It is replaced with a crucial discussion of the role of divine ordination for human merit. Thomas writes:

But the mode and measure of human virtue in a person is from God. And for that reason a person cannot merit before God except according to the presupposition of divine ordination (divinae ordinationis), namely, that a person obtains from God something like a reward for his operation [or works], what God gave (deputavit) him the power of operation for. So also natural things by their proper movements and operations obtain to that for which they were ordained by God. Nevertheless [human beings obtain it] differently because the rational creature moves himself to action through the free will; wherefore his action has the ratio of merit, which is not the case in other creatures. ${ }^{37}$

35 ST I-II: 113, proem.

36 ST I-II: 112, 3 c. Cf. S Colberg's Wayfarer's End, chapter three, for an extended discussion of this development; cf. also M. Seckler, Instinkt und Glaubenswille nach Thomas von Aquin (Mainz 1961), pp. 90-98.

37 ST I-II: 114, 1 c. Wawrykow offers the authoritative exposition of ordinatio in relation to Thomas's conception of merit; cf. God's Grace, pp. 180-86. Ordinatio gestures to God's sapiential and providential ordering of the cosmos wherein merit represents one category by which God moves human actors to their predestined end. 
Thomas does not stress the supernatural value of good works; rather, God ordains to reward human beings for the proper and cooperative use of their free wills (in love) so that they receive as a reward what God has elected to give them. Divine ordination relieves the need to stress equality between God and the human being in order to see merit as just. The stress on condign merit is concomitantly relaxed. While Thomas permits talk of condign merit, he does so only on the condition that the meritorious work is credited to the Holy Spirit as principle actor. ${ }^{38}$ If merit refers to the free will's cooperation with God's movement, it must be viewed as congruent and premised on God's ordination. Compared with the Scriptum, then, the Summa theologiae detaches the moments of conversion and continuance in a state of grace from the language of merit through emphases on operative auxilium and the state of fallen nature. It further narrows the scope of merit to increases in grace and the reward of eternal life under the heading of congruent merit. Human beings remain free and genuine participants in their movement to union with God even as their cooperation always remains secondary and made by possible by God's motion and habitual gifts.

Thomas's appreciation for divine ordination underscores a further and critical point of development in the Summa: discussions of grace, justification, and merit are linked inextricably to divine predestination. Two short points illumine this linkage. First, because God has predestined some to glory, Thomas reasons that God gives graces that convert sinners and facilitate cooperation with God. Justification and merit depend entirely on God's election in love of some to eternal life. ${ }^{39}$ The Summa frequently uses the language of divine auxilium to explain the effects of predestination in the recipient. ${ }^{40}$ Second, its treatment

38 Thomas writes: "If, however, we speak of meritorious work insofar as it proceeds from the grace of the Holy Spirit, it is meritorious of eternal life condignly. For then the value of the merit follows from the power of the Holy Spirit moving (moventis) us into eternal life" (ST I-II: 114, 3 c). Thomas credits the Holy Spirit in a cooperative effect of grace as having condignity with the reward, but he reserves congruency for the secondary human actor in the same act. For a further discussion of the instinctus of the Holy Spirit and auxilium, cf. S. Colberg, "Auxilium," pp. 207-09.

39 Introducing predestination, Thomas writes: "For if a thing is not able to arrive at something through the power of its own nature, it ought to be moved there by another; just as an arrow is sent to the mark by the archer. Wherefore, properly speaking, a rational creature who is capable of eternal life is led to it, as if sent there, by God. The reason for that direction preexists in God" (ST I: 23, 1 c).

40 Thomas states: "And so it is impossible that the whole of the effect of predestination in general should have any cause on our part. Because whatever is in a person ordering him towards salvation is also held together under the effect of predestination; even the 
of predestination cites Augustine's On the Predestination of the Saints five times in support of the priority of predestination to grace as well as the notion that predestination does not destroy human contingency. ${ }^{41}$ Paralleling Augustine's claim that "predestination is preparation for the gift and grace is the gift itself," Thomas establishes a causal ordo in which predestination - flowing from the divine will - sets in motion (1) the preparation of the sinner for justification, (2) the on-going provision of graces that heal, elevate and motivate the recipient, and (3) the reward of human actions with further graces and final glory. ${ }^{42}$ The late Augustine's affirmation of predestination goes far in framing the causal order of human salvation that Thomas features in the Summa theologiae.

\section{The Place of Augustine in Thomas's Mature Theology of Grace}

At least three vital influences contribute to the Summa's developments over the Scriptum. First, but perhaps not foremost, the Summa makes explicit use of Augustine's anti-Massilian works in ways not found in his earlier writings. Henri Bouillard and others have successfully demonstrated that Thomas's use of the late Augustine likely involved an encounter with the original texts - probably for the first time outside of florilegia. Thomas cites On the Predestination of the Saints and On the Gift of Perseverance at critical points in his discussion of grace - including in the affirmation of predestination, the revision of the facienti quod in se est, and his stress on perseverance. ${ }^{43}$ Thomas refines the cat-

preparation for grace itself, which can never be done except through divine auxilium" (ST I: 23, 5 c, emphasis mine).

41 References include I: 23, 1 ob. 3; I: 23, 2 ob. 2; I: 23, 2 ob. 3; I;23, 2 sc.; and I;23, $5 \mathrm{ob}$. 2. Thomas also references the anti-Massilian works five times in the treatise on grace: I-II: 109, 10 sc; I-II: 110, 3 sc; I-II: 112, 3 c; I-II: 113, 10 sc; and I-II: 114, 9 ob.1.

42 Augustine writes: And between grace and predestination the only difference is this, that predestination is the preparation for grace, while grace is the gift itself. Thus when the Apostle says, 'Not of works, that no man may glory. For we are his workmanship, created in Christ Jesus in good works,' he speaks of grace, but when he says follows 'what God has prepared that we should walk in them,' he speaks of predestination" (On the Predestination of the Saints, 10, p. 24). Burns explains Augustine's position: "God's predestination is his knowledge and preparation of the gifts which he will give and those to whom he will give them; his grace follows as the actual giving and achievement. To reject predestination, therefore, one must either deny divine foreknowledge or assert that salvation is accomplished by autonomous human works rather than by the gifts of God" (The Development, pp. 176-77).

43 Bonner explores Augustine's increasing stress on the operative character of grace for sinners and in the work of perseverance: "Augustine was convinced that the Fall has so 
egory of operative grace used by Augustine, specifically stressing the notion that God's grace must "operate" or work the recipient's conversion, continuance in grace, and arrival at final glory. ${ }^{44}$ The Summa's treatise on grace further sets this language of operation into a schema of predestination and divine ordination where operative graces actualize the ordo of salvation. Thomas's mature teaching on grace thus shows a debt to the late Augustine as an authority. In that sense one may reasonably conclude that Thomas's mature theology of grace is "thoroughly Augustinian." At the same time, Thomas's treatise is also "thoroughly Pauline" and "thoroughly attuned to God as efficient cause of human salvation." Thomas quotes Paul with regularity when noting the effects of sin and restricting human merit from the first grace. ${ }^{45}$ By most accounts, Thomas's second commentary on the Pauline corpus follows his writing of the Prima Secundae. Still, the Summa shows more explicit attention to Paul's theology than does the Scriptum. Emphasis on divine sovereignty and the ordo of human salvation holds that, even when a person cooperates to earn rewards, there can be no boasting. Like Paul, Thomas stresses that both the gifts and rewards of human salvation flow from God's gracious ordering of the cosmos; that order integrates and honors human action as rational and free, but it sets it firmly and secondarily as an effect of God's will and grace. ${ }^{46}$ Augustine is also indebted to the Pauline corpus so that isolating what is specifically Pauline ver-

corrupted the human will that it necessitated a specific impulse of divine grace for every righteous human action, however trivial, even after baptism, so that even the saintliest persons to the end of their lives needed to pray deliver us from evil" (Freedom and Necessity, p. 120). Burns argues that the anti-Massilian works represent the final development of Augustine's views on operative and cooperative grace; cf. The Development, pp. 172-73.

${ }^{44}$ Wawrykow writes: "Just as God must work the conversion of the sinner, so too, Augustine says, God must freely keep the justified in a state of grace, moving the justified to reject the continued temptations of sin and to perform the good works which God desires" (God's Grace, p 272).

45 Cf. H. Bouillard, Conversion et grace, pp. 135-150 and J. Wawrykow's God's Grace, pp. 279-84 for discussions of Thomas's use of Paul as an authority. In Paul in the Summa Theologiae (Washington D.C. 2014), M. Levering observes the Pauline dimensions of ST I-II: 109-114; he writes: "In fact, in the forty-four articles found in questions 109-114 of the prima-secundae pars, Pauline citations occur seventy times - a significant number but somewhat less than one might have guessed. A glance at the articles suggests a possible reason: Aquinas relies heavily on Augustine. Since Augustine's theology of grace is profoundly Pauline, this might explain why Paul is not directly quoted more often. With that said, seventy citations is still a large number, and we can be sure that we will gain insight into Aquinas's treatise by exploring his citations of Paul" (p. 155).

${ }^{46}$ Cf. S. Colberg. The Wayfarer's End, Chapter 6 and appendix on Paul's letters. See also the volume Towards a Biblical Thomism, P. Roszak and J. Vijgen, (eds.), (Navarra, 2018 
sus Augustinian resists easy classification. ${ }^{47}$ In any case, the new and prominent themes of the Summa's treatise on grace seem indebted to Paul in ways similar to Augustine.

The glue which links Augustine and Paul most firmly to the Summa's treatment of grace is nevertheless Thomas's wide affirmation of God's efficient causality, here parsed mainly in terms of divine motion and its effects in divine auxilium and operative grace. As Thomas synthesizes Aristotelean notions of motion and God's ordination of the cosmos, efficient causality - divine motion - emerges as central to actualizing human salvation. ${ }^{48}$ Divine motion allows Thomas to think of predestination as something which frames all provisions of grace, including its critical effects in conversion, perseverance, and final glory. Predestination in not simply a formal cause in God's intellect; it is God's on-going efficient action in the life of the elect so that, as Augustine claims, God operates in the discrete acts of human life that approach the horizon of salvation. Emphasizing efficient causality tightens the connection between divine and human actions, and it shifts the conception of what human progress to union with God means. Specifically, even cooperative actions flow from the movement and instinctus of the Holy Spirit in the life of the wayfarer; there is never a time when the reward of cooperative grace is not first reckoned to God and only then to the human agent. Thomas's appreciation of divine motion and divine auxilium provide a new dynamism in the relationship of divine and human action which consistently affirms divine action. Therefore, while Thomas's theology shows connection with the full texts of Augustine's anti-Massilian works, it is also reasonable to argue that Thomas's development of divine auxilium rehabilitates the late Augustine. As evidenced in our analysis of the Scriptum, largely formal accounts of grace make it difficult to conceive of a relationship between divine willing and free human action; they consequently tend to leave the scope of merit more open than either Augustine or Thomas permits in their mature works. Thomas's re-conception of divine motion and its expression as

), particularly Anthony Giambrone's “The Prologues to Aquinas' Commentaries on the Letters of Saint Paul," 23-38.

47 Bonner observes important links between Augustine's reading of Romans and First Corinthians in Freedom and Necessity, pp. 42-44.

48 Lonergan writes: "Only when St. Thomas settled down to the vast task of thinking out the Christian universe in the Contra gentiles did he arrive at the truth that divine providence is an intrinsically certain cause of every combination or interference of terrestrial causes. By the same stroke [he arrived] at the practically identical truth that God applies every agent to its activity. Accordingly, we are led to infer that the essence of the idea of application is the Aristotelian premotion as informed by the Thomist causal certitude of divine providence" (Grace and Freedom, p. 80). 
divine auxilium allow Thomas to re-deploy Augustine in ways that were useful and warranted in the $13^{\text {th }}$ century. In this sense Aquinas's re-use of Augustine does not simply introduce Augustine as an authority. Rather, it makes fundamental insights by the Doctor of Grace available in generative and constructive ways for theologians following Saint Thomas.

\section{Bibliography}

Aquinas, T., Scriptum super libros sententiarum, 4 vols., P. Mandonnet and M.F. Moos (eds.), Paris 1933-47.

Aquinas, T., Summa theologiae, 5 vols., Ottawa 1941-1945.

Augustine, On the Gift of Perseverance, in Four Anti-Pelagian Writings, J.A. Mourant and W.J. Collinge (trans.), Washington, D.C. 1992, pp. 271-337.

Augustine, On the Predestination of the Saints, in Four Anti-Pelagian Writings, J.A. Mourant and W.J. Collinge (trans.), Washington, D.C. pp. 218-270.

Bouillard, H., Conversion et grace chez S. Thomas d'Aquin, Paris 1944.

Bonner, G. Freedom and Necessity: Saint Augustine's Teaching on Divine Power and Human Freedom, Washington, D.C. 2007.

Burns, J.P., The Development of Augustine's Doctrine of Operative Grace, Paris1980.

Colberg, S., "Aquinas and the Grace of Auxilium," Modern Theology 32 (2016) 207-09.

Colberg, S., The Wayfarer's End: Bonaventure and Aquinas on Divine Rewards in Scripture and Sacred Doctrine, Washington, D.C. forthcoming.

Lonergan, B., Grace and Freedom: Operative Grace in the Thought of St. Thomas Aquinas, J.P. Burns (ed.), London 1971.

Levering, M., Paul in the Summa Theologiae, Washington, D.C. 2014.

Roszak, P., "The Place and Function of Biblical Citations in Thomas's Aquinas's Exegesis," in Reading Sacred Scripture with Thomas Aquinas: Hermeneutical Tools, Theological Questions, and New Perspectives, P. Roszak and J. Vijgen, (eds.), (Turnhout, ), 115-140.

Roszak, P. and J. Vijgen, Reading Sacred Scripture with Thomas Aquinas: Hermeneutical Tools,

Theological Questions, and New Perspectives, Navarra, 2018.

Seckler, M., Instinkt und Glaubenswille nach Thomas von Aquin, Mainz 1961.

Torrell, J.P., Saint Thomas Aquinas, vol. 1, R. Royal (trans.), Washington, D.C. 1996.

Wawrykow, J., "Grace," in The Theology of Thomas Aquinas, R. Van Nieuwenhove and J. Wawrykow (eds.), South Bend 2005, pp. 192-221.

Wawrykow, J., God's Grace and Human Action: 'Merit' in the Theology of Thomas Aquinas, South Bend 1995.

Wawrykow, J., "Perseverance in $13^{\text {th }}$-Century Theology: the Augustinian Contribution," Augustinian Studies 22 (1991) 125-40. 